\title{
Two-Dimensional Electrophoretic Analysis of Nuclear Acidic Proteins in Senescent Human Diploid Cells
}

\author{
Hiroshi Sakagami ${ }^{1 *}$, Youji Mitsui ${ }^{1}$, Sei-itsu Murota $^{1}$ and Masa-atsu \\ Yamada $^{2}$ \\ 1 Department of Pharmacology, Tokyo Metropolitan Institute of Gerontology, \\ Tokyo 173, Japan and ${ }^{2}$ Department of Physiological Chemistry, Faculty of \\ Pharmaceutical Sciences, University of Tokyo, Tokyo 113, Japan
}

\begin{abstract}
Nuclear acidic proteins solubilized from young and senescent human diploid fibroblasts were analyzed by two-dimensional gel electrophoresis. The age-related increase in nuclear proteins was due mainly to the accumulation of residual acidic proteins. Differences in seven major nuclear acidic proteins between young and senescent cells were observed. [ $\left.{ }^{35} \mathrm{~S}\right]-$ menthionine autoradiography showed that senescent cells had lost the ability to synthesize detectable amounts of four major proteins that are found in young cells. In addition, senescent cells synthesized two new major proteins that were undetectable in young cells. The isoelectric point of a single polypeptide with the molecular weight 37,000 seemed to shift from 5.3 to 5.8 with cellular aging.
\end{abstract}

Cultured diploid fibroblasts with a finite lifespan have been used as a model system to study cellular aging $(6,7)$. The inverse relationship between human donor age and the remaining in vitro lifespan has validated the use of cultured human diploid fibroblasts for the study of human cellular aging $(21,22)$.

Results based on the cytoplasmic hybridization technique have suggested nuclear control of cellular aging (27). Several investigators have reported age-related alterations in chromatin structure and function in this system $(12,20,24)$. However, changes in the nuclear constituents of cultured fibroblasts due to aging have been studied in far less detail $(5,8,25)$. The techniques used have not been adequate for the resolution of most of the individual proteins from the highly diverse population of nonhistone chromosomal proteins, as suggested by the work of Peterson and McConkey who assayed the proteins from HeLa cells with two-dimensional gel electrophoresis (19).

We previously reported an increase in nuclear size of slowly- or non-dividing cells in senescent human diploid fibroblasts (14). The main aim of our present study was to analyze the nuclear proteins that accumulate with cellular aging with a two-dimensional gel electrophoresis technique (17).

\section{MATERIALS AND METHODS}

Cell culture. The cells used in this study were TIG-1, a human fetal lung fibroblast strain established and characterized in The Tokyo Metropolitan Institute of Gerontology. They were cultured in Eagle's Basal Medium (BME) (GIBCo) supplemented with glutamine,

* Ph. D. Fellow of the University of Tokyo 
$10 \%$ fetal bovine serum (FBS) (GIBCo), $100 \mu \mathrm{g} / \mathrm{ml}$ of streptomycin sulfate and 100 units $/ \mathrm{ml}$ of penicillin $\mathrm{G}$ potassium. Cultures were maintained at $37^{\circ} \mathrm{C}$ in a humidified incubator under a 95:5 (air: $\left.\mathrm{CO}_{2}\right)$ atmosphere. Routine subcultivations were performed at a 1:4 split ratio once a week with one intervening change of medium. The doubling time of TIG-1 cells was $17-23 \mathrm{~h}$ at the middle passage. The average in vitro lifespan of TIG-1 cells in this laboratory was 63 population doublings.

Isotope labeling. For experimental use, cells were plated on glass petri dishes $(15 \mathrm{~cm}$ in diameter) at a 1:4 split ratio and allowed to grow to confluence with three intervening changes of medium at 3,6 , and 8 days after plating. $20 \mathrm{~h}$ after the last change of medium, the cell layers were washed with methionine-free medium, then incubated for $4 \mathrm{~h}$ at $37^{\circ} \mathrm{C}$ with $15 \mathrm{ml}$ of fresh methionine-free medium containing [ ${ }^{35} \mathrm{~S}$ ]-methionine (final $5 \mu \mathrm{Ci} / \mathrm{ml}$, $1005 \mathrm{Ci} / \mathrm{mmol}$, the Radiochemical Centre, Amersham). After incubation, the radioactive medium was removed, and the monolayers were washed well with phosphate buffered saline free of $\mathrm{Ca}^{++}$and $\mathrm{Mg}^{++}$ions (PBS (-)) that contained $750 \mu \mathrm{g} / \mathrm{ml}$ of methionine. TIG-1 cells at the preconfluent stage were incubated with [ ${ }^{3} \mathrm{H}$ ]-thymidine (final $0.02 \mu \mathrm{Ci} / \mathrm{ml}$, the Radiochemical Centre, Amersham) for $48 \mathrm{~h}$ to label DNA.

Isolation of nuclei. Nuclei were isolated by a modification of the procedure of Senshu and Ohashi (23). All subsequent operations were conducted at $0-4^{\circ} \mathrm{C}$ unless otherwise stated. When confluent TIG-1 cells were harvested by scraping them off with a rubber policeman, the nuclei passed through $2.3 \mathrm{M}$ sucrose were contaminated with fibrous substances. Therefore, it was necessary to isolate pure nuclei from the harvested cells by treating the cells with $0.25 \%$ trypsin. Immediaiely after cells had been detached by trypsin, growth medium containing $20 \%$ FBS was added to stop the trypsin action. Cells $\left(1 \times 10^{7}\right)$ were washed twice with PBS(-) and twice with buffer A (10 mM Tris- $\mathrm{HCl}, \mathrm{pH} 7.4,10 \mathrm{mM} \mathrm{KCl}$, $5 \mathrm{mM} \mathrm{CaCl}_{2}$ and $0.1 \mathrm{mM}$ phenylmethylsulfonyl fluoride (PMSF)) and collected by spinning them at 1,500 rpm for $5 \mathrm{~min}$. PMSF was used, as described by Nooden et al. (16), to inhibit the degradation of nuclear proteins. Collected cells then were suspended in $2 \mathrm{ml}$ of buffer $\mathbf{B}$ $(0.5 \%$ Triton X-100 in buffer A) after which they were homogenized with 20 strokes in a Teflon-glass homogenizer. After spinning the sample at 1,500 rpm for $5 \mathrm{~min}$, the supernatant (cytoplasm) was discarded. At this stage, $91-97 \%$ of the cellular DNA was recovered from the nuclear pellet (referred to as crude nuclei). These crude nuclei were suspended in $1 \mathrm{ml}$ of buffer $\mathrm{C}\left(0.25 \mathrm{M}\right.$ sucrose, $10 \mathrm{mM}$ Tris- $\mathrm{HCl}$, pH 7.4, $5 \mathrm{mM} \mathrm{CaCl}_{2}, 0.5 \%$ Triton X-100 and $0.1 \mathrm{mM}$ PMSF) then mixed with $2 \mathrm{ml}$ of buffer $\mathrm{D}$ ( $2.3 \mathrm{M}$ sucrose, $10 \mathrm{mM}$ Tris-HCl, pH 7.4, $5 \mathrm{mM} \mathrm{CaCl}_{2}$ and $0.1 \mathrm{mM}$ PMSF). The suspension was carefully layered on the top of $2 \mathrm{ml}$ of buffer $\mathrm{D}$ in an ultracentrifuge tube and spun at $53,000 \times \mathrm{g}$ for $60 \mathrm{~min}$ in the SW 50.1 rotor of a Beckman ultracentrifuge. The pellet was washed with buffer $\mathrm{E}$ (buffer $\mathrm{C}$ without Triton $\mathrm{X}-100$ ); this was the purified nuclei. The presence of $5 \mathrm{mM} \mathrm{CaCl}_{2}$ in the isolation buffers effectively diminished nuclear aggregation.

Fractionation of nuclear proteins. Nuclear proteins were fractionated into $0.15 \mathrm{M} \mathrm{NaCl}$ soluble proteins, $0.4 \mathrm{~N} \mathrm{H}_{2} \mathrm{SO}_{4}$ extractable proteins (mainly histones), and residual acidic proteins (26). Purified nuclei were suspended in $0.5 \mathrm{ml}$ of buffer $\mathrm{F}(0.15 \mathrm{M} \mathrm{NaCl}, 10 \mathrm{mM}$ Tris- $\mathrm{HCl}, \mathrm{pH} 8.0$ and $0.1 \mathrm{mM}$ PMSF) and centrifuged at $1,500 \mathrm{rpm}$ for $5 \mathrm{~min}$. This process was repeated twice. The combined supernatants were used to determine the amount of 0.15 $\mathrm{M} \mathrm{NaCl}$ soluble protein. Histones were extracted from the pelleted nuclei by incubation with $1 \mathrm{ml}$ of $0.4 \mathrm{~N} \mathrm{H}_{2} \mathrm{SO}_{4}-0.1 \mathrm{mM}$ PMSF at $0^{\circ} \mathrm{C}$ for $2 \mathrm{~h}$, then centrifuging the nuclei at 10,000 $\mathrm{rpm}$ for $20 \mathrm{~min}$ in a Sorvall RC2-B. The supernatants were used to determine the amount of proteins and were called the $0.4 \mathrm{~N} \mathrm{H}_{2} \mathrm{SO}_{4}$ extractable proteins. Proteins that were not extracted with $0.4 \mathrm{~N} \mathrm{H}_{2} \mathrm{SO}_{4}$ were called residual acidic proteins. Using SDS polyacrylamide 
gel electrophoresis, we observed that no histones were detectable in the fractions of the residual acidic, $0.15 \mathrm{M} \mathrm{NaCl}$ soluble, and cytoplasmic proteins (data not shown).

Solubilization of urea-soluble nuclear acidic proteins. Nuclear pellets obtained after the extraction of $0.15 \mathrm{M} \mathrm{NaCl}$ soluble proteins were suspended in $50-100 \mu \mathrm{l}$ of lysis buffer (9.5 M urea, 5\% 2-mercaptoethanol, 2\% Nonidet P-40, 1.6\% Ampholines, pH 5-7 and 0.4\% Ampholines, $\mathrm{pH} 3.5-10$ ) and left at room temperature for $10 \mathrm{~min}$ with occasional agitation. The supernatants separated after centrifugation at $15,000 \mathrm{rpm}$ for $20 \mathrm{~min}$ in a Sorvall RC2-B were called urea-soluble nuclear acidic proteins, and stored at $-70^{\circ} \mathrm{C}$. Proteins that were not extracted with the lysis buffer were called urea-insoluble nuclear proteins.

Polyacrylamide gel electrophoresis. The urea-insoluble proteins were sonicated in $2 \%$ SDS and well dialyzed against the SDS sample buffer $(62.5 \mathrm{mM}$ Tris- $\mathrm{HCl}, \mathrm{pH} 6.8,0.1 \%$ SDS, $1 \%$ 2-mercaptoethanol, $10 \%$ glycerol and $0.1 \mathrm{mM} \mathrm{PMSF).} \mathrm{The} \mathrm{urea-soluble} \mathrm{nuclear}$ proteins in the lysis buffer were dialyzed directly against the same buffer. Both samples were applied to SDS $10 \%$ polyacrylamide gel electrophoresis under the conditions used by Laemmli (9). Histones were extracted from the urea-insoluble pellet with $1 \mathrm{ml}$ of $0.4 \mathrm{~N}$ $\mathrm{H}_{2} \mathrm{SO}_{4}-0.1 \mathrm{mM}$ PMSF at $0^{\circ} \mathrm{C}$ for $2 \mathrm{~h}$, then they were centrifuged at $10,000 \mathrm{rpm}$ for $20 \mathrm{~min}$ in a Sorvall RC2-B. Supernatants were precipitated with trichloroacetic acid (TCA, final $25 \%(\mathrm{w} / \mathrm{v}))$, then washed once in acidified acetone $(1 \mathrm{ml}$ of acetone $+10 \mu \mathrm{l}$ of conc. $\mathrm{HCl})$, and three times in acetone. After the complete evaporation of acetone, the dried histones were solubilized with $7 \mathrm{M}$ urea-5\% 2-mercaptoethanol- $0.9 \mathrm{~N}$ acetic acid, then electrophoresed on $0.5 \times 15 \mathrm{~cm}$, acid-urea $15 \%$ polyacrylamide gels containing $2.5 \mathrm{M}$ urea according to the method of Panyim and Chalkley (18). The urea-soluble nuclear proteins were precipitated with TCA and subjected to acid-urea gels in the same manner. The gels were stained with either $0.05 \%$ amido black $10 \mathrm{~B}$ in $10 \%$ acetic acid $-30 \%$ methanol or $0.06 \%$ Coomassie brilliant blue G250 in 5\% TCA-3.2\% sulfosalicylic acid-50\% ethanol (in case gels contained Ampholines). Excess dyes were removed by repeated washings with $10 \%$ acetic acid- $30 \%$ methanol or $10 \%$ acetic acid- $25 \%$ ethanol. Stained gels were scanned at $560 \mathrm{~nm}$ in a Cosmo D-101 densitometer (Cosmo Co., Tokyo).

Two-dimensional gel electrophoresis. Cytoplasmic or $0.15 \mathrm{M} \mathrm{NaCl}$ soluble nuclear proteins were dialyzed against $0.2 \mathrm{M}$ triethylammonium bicarbonate buffer, $\mathrm{pH} 7.8$ with $1 \%$ 2-mercaptoethanol, then they were lyophilized as described by Peterson and McConkey (19). The residue was solubilized with the above lysis buffer. Nuclear urea-soluble acidic proteins (200,000 TCA insoluble $\mathrm{cpm})$ underwent two-dimensional gel electrophoresis directly, according to the method of O'Farrell (17). The gels were dried for $2 \mathrm{~h}$ in an aspirator with evacuation and heating. The dried gels were exposed to Kodak X-Omat films (Eastman Kodak Co.) for a period ranging from 10 days to 1 month. The $x$-ray film was then developed for $5 \mathrm{~min}$ in Konishiroku x-ray developer and replenisher after which it was fixed for $10 \mathrm{~min}$ in Konishiroku fixer.

To determine the $\mathrm{pH}$ gradient of the first dimension gels, we placed $0.5 \mathrm{~cm}$ slices of gel in $0.5 \mathrm{ml}$ of freshly deionized degassed water for $4 \mathrm{~h}$. The $\mathrm{pH}$ of each fraction was then measured.

Actin was identified by coelectrophoresis of the labeled sample with unlabeled purified rabbit skeletal muscle actin provided by $\mathrm{R}$. Yoshimoto (University of Tokyo).

Detection of radioactivity. Two microliters of the sample was mixed with $0.5 \mathrm{ml}$ cold distilled water, one drop of $2 \%$ bovine serum albumin, and $0.5 \mathrm{ml} 40 \%$ TCA- $0.1 \mathrm{M}$ sodium pyrophosphate. After standing at $0^{\circ} \mathrm{C}$ for $20 \mathrm{~min}$, the acid-insoluble material was collected on a glass fiber filter (Whatman GF/C), which then was washed with $5 \times 3 \mathrm{ml}$ of $10 \%$ TCA$0.05 \mathrm{M}$ sodium pyrophosphate $\left(0^{\circ} \mathrm{C}\right), 1 \times 3 \mathrm{ml}$ of ethanol $\left(25^{\circ} \mathrm{C}\right)$, and $1 \times 3 \mathrm{ml}$ of acetone 
$\left(25^{\circ} \mathrm{C}\right)$. The filters were dried and counted by scintillation spectrometry in $10 \mathrm{ml}$ of toluene scintillation fluid containing $50 \mathrm{mg}$ of PPO and $3 \mathrm{mg}$ of dimethyl POPOP.

Chemical determinations. The amount of protein was determined by the method of Lowry (10) and that of DNA by Burton's diphenylamine reaction (3). Bovine serum albumin (Fraction V, Wako) was used as the standard of protein and calf thymus histone (Type II, Sigma) for the histone determination. Calf thymus DNA (Type I, Sigma) was used as the standard for DNA after correction for its moisture content.

Histones in $0.4 \mathrm{~N} \mathrm{H}_{2} \mathrm{SO}_{4}$ were neutralized with $\mathrm{NaOH}$ before protein determination. The nuclear pellet and the other fractions were precipitated with $25 \%$ TCA and solubilized with $0.4 \mathrm{~N} \mathrm{NaOH}-4 \%$ SDS.

\section{RESULTS}

Increase in nuclear residual acidic proteins with aging. Since it has been reported that differences detected in the arrested state of cell growth may be associated with fundamental alterations in the chromosomal proteins of populations of different age (5) and that cell volume reached a plateau at a stationary phase of cell growth (13), we used cells at the confluent stage in this investigation.

Before we examined the changes in nuclear proteins with aging, we first investigated the effect of trypsin on the recovery of histones because trypsinization of resting cells might result in a loss of nuclear proteins (11). Cells were harvested either by treatment with $0.25 \%$ trypsin or by scraping them off with a rubber policeman. Histones were extracted from the purified nuclei of both samples. As shown in Table 1, cell trypsinization did not cause any loss of $0.4 \mathrm{~N} \mathrm{H}_{2} \mathrm{SO}_{4}$ extractable proteins from the nuclei $(105 \%$. of those in the scraped cell nuclei). Since histones were approximately 70 percent of the $0.4 \mathrm{~N} \mathrm{H}_{2} \mathrm{SO}_{4}$ extractable proteins in both the trypsinized and scraped cell nuclei, recovery of the total amount of histones per DNA was not decreased by cell trypsinization. Science histone $\mathrm{H} 1$ is highly susceptible to proteolytic degradation (4), we

TABLE 1. INCREASE IN NUCLEAR RESIDUAL ACIDIC PROTEINS DURING THE LIFESPAN OF TIG-1 CELLS

\begin{tabular}{|c|c|c|c|c|c|c|c|}
\hline \multirow[t]{2}{*}{ Harvest } & \multirow{2}{*}{$\begin{array}{c}\text { Population } \\
\text { doubling } \\
\text { level }\end{array}$} & $\begin{array}{l}\text { mg total } \\
\text { nuclear } \\
\text { proteins }\end{array}$ & $\begin{array}{c}\text { mg residual } \\
\text { acidic } \\
\text { proteins } \\
\end{array}$ & $\begin{array}{c}\text { mg } 0.15 \mathrm{M} \\
\mathrm{NaCl} \\
\text { soluble } \\
\text { proteins } \\
\end{array}$ & $\begin{array}{c}\mathrm{mg} 0.4 \mathrm{~N} \\
\mathrm{H}_{2} \mathrm{SO}_{4} \\
\text { extractable } \\
\text { proteins } \\
\end{array}$ & \multirow{2}{*}{$\frac{\text { Histone } \mathrm{Hl}^{\mathrm{a}}}{\begin{array}{c}\text { Total } \\
\text { histones }\end{array}}$} & \multirow[t]{2}{*}{$(\%)$} \\
\hline & & mgDNA & mgDNA & mgDNA & mgDNA & & \\
\hline \multirow{2}{*}{$\begin{array}{l}\text { Rubber } \\
\text { policeman }\end{array}$} & $10-29$ & & & & $1.00 \pm 0.05$ & $17.4 \pm 0.6$ & ( 8 ) \\
\hline & $30-49$ & & & & $0.95 \pm 0.03$ & & (5) \\
\hline \multirow[t]{3}{*}{ Trypsin } & $10-29$ & $3.49 \pm 0.15$ & $2.08 \pm 0.11$ & $0.33 \pm 0.06$ & $1.10 \pm 0.05$ & $17.0 \pm 0.2$ & (10) \\
\hline & $30-49$ & $4.07 \pm 0.43$ & $2.56 \pm 0.34$ & $0.45 \pm 0.04$ & $1.06 \pm 0.06$ & & ( 8$)$ \\
\hline & $50-69$ & $5.14 \pm 0.40$ & $3.30 \pm 0.32$ & $0.54 \pm 0.08$ & $1.25 \pm 0.06$ & & (12) \\
\hline
\end{tabular}

Cells were harvested either by treatment with trypsin or by scraping them off with a rubber policeman. Purified nuclei were obtained, and nuclear proteins were fractionated into $0.15 \mathrm{M} \mathrm{NaCl}$ soluble proteins, $0.4 \mathrm{~N} \mathrm{H}_{2} \mathrm{SO}_{4}$ extractable proteins, and residual acidic proteins as described in MATERIALS AND METHODS.

a The proportion of histone $\mathrm{Hl}$ to total histone was determined from the densitometrical analysis of $0.4 \mathrm{~N} \mathrm{H}_{2} \mathrm{SO}_{4}$ extractable proteins subjected to acid-urea gel electrophoresis.

Each value represents the mean \pm S.E.

Numbers in parentheses are the number of experiments. 
examined the proportion of histone $\mathrm{H} 1$ to total histones by densitometric analysis. No significant difference in the amount of histone $\mathrm{H} 1$ was found between trypsinized cell nuclei and scraped cell nuclei (Table 1).

Fig. 1 shows that at the terminal phase the cell number at harvest time declined abruptly. The amounts of cellular proteins as well as of nuclear proteins per DNA increased with aging. The amount of DNA per cell was constant during the lifespan of the TIG-1 cells.

To examine which component of the nuclear proteins is responsible for this agerelated increase, we fractionated the nuclear proteins into three distinct fractions. As shown in Table 1, residual acidic proteins accounted for 62 percent of the total nuclear proteins and they increased progressively with cellular aging. The $0.4 \mathrm{~N} \mathrm{H}_{2} \mathrm{SO}_{4}$ extractable proteins did not change significantly. The $0.15 \mathrm{M} \mathrm{NaCl}$ soluble proteins were only 10 percent of the total nuclear proteins and were comprised of many proteins common to cytoplasmic proteins (Fig. 2). Therefore, the increase in nuclear proteins with aging was mainly due to the increase in residual acidic proteins.

Two-dimensional electrophoretic analysis of nuclear acidic proteins. We examined the increased residual acidic proteins in senescent cells in more detail with two-dimensional gel electrophoresis (17). However, it was difficult to solubilize the residual acidic proteins in the lysis buffer. Residual acidic proteins should be almost the same as the urea-soluble nuclear acidic proteins. Therefore, we extracted the nuclear acidic

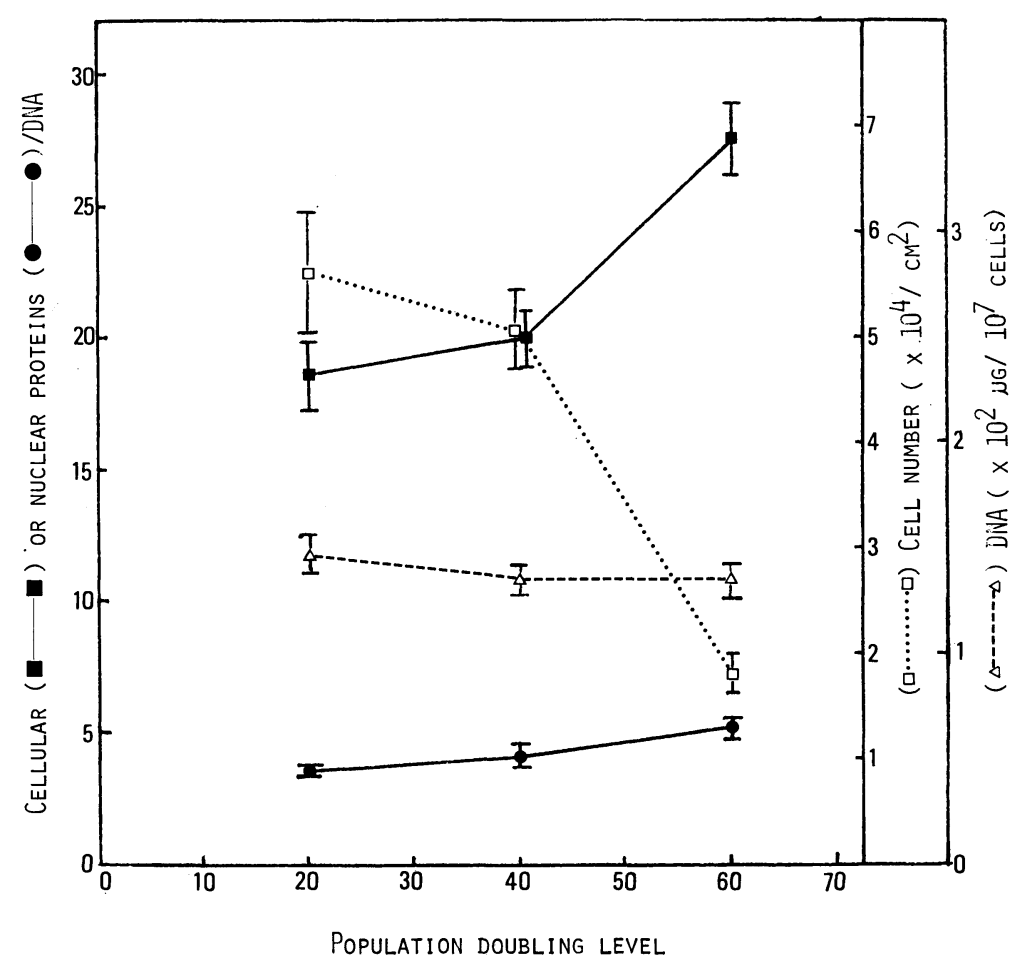

Fig. 1. Amount of protein and cell number as a function of the population doubling level.

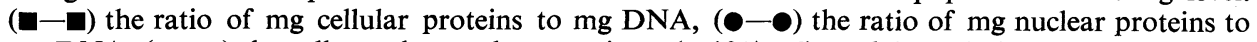
mg DNA, $(\square \cdots \square)$ the cell number at harvest time, $\left(\times 10^{4} / \mathrm{cm}^{2}\right)$, and $(\triangle \cdots \triangle)$ the amount of DNA $\left(\times 10^{2} \mu \mathrm{g} / 10^{7}\right.$ cells $)$. Each point was determined from 8-12 samples and represents the mean \pm S.E. 


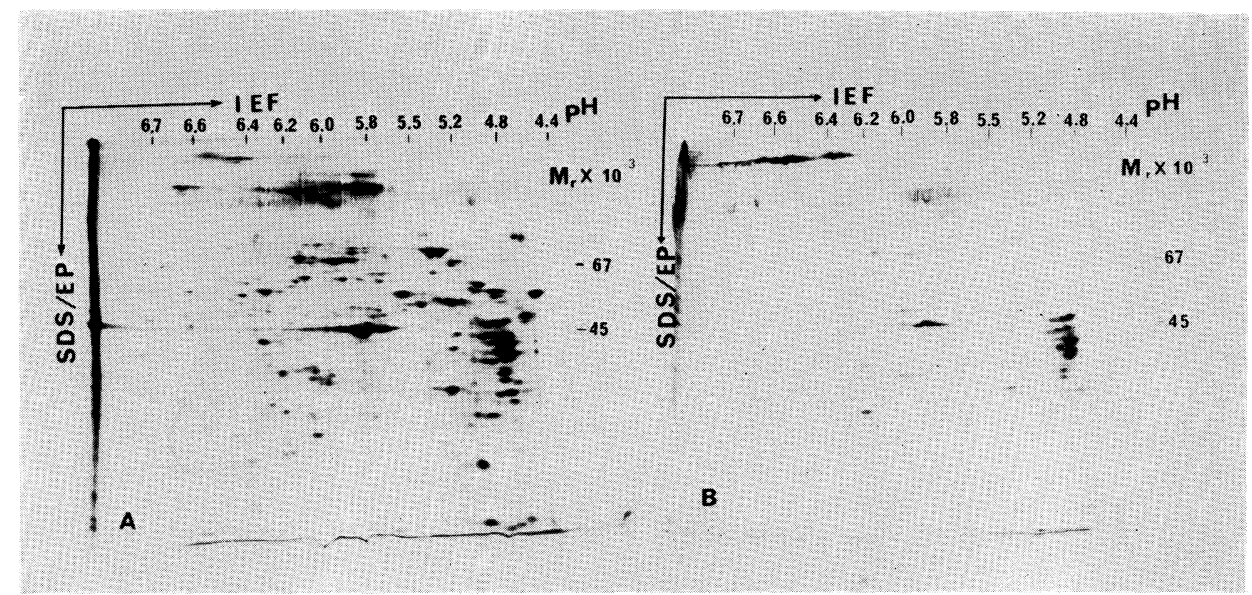

Fig. 2. Autoradiographies of two-dimensional gels containing [ $\left.{ }^{55} \mathrm{~S}\right]-$ methionine labeled proteins. The first-dimensional isoelectric-focusing gels were loaded with 375,000 TCA insoluble cpm. Autoradiograms were obtained after a 1 month exposure. The $\mathrm{pH}$ gradient, molecular weight calibration, and two-dimensional gel electrophoresis were carried out as described in MATERIALS AND Methods. (A) Cytoplasmic and (B) $0.15 \mathrm{M} \mathrm{NaCl}$ soluble nuclear proteins of TIG-1 cells at 27 PDL.

proteins by incubating the $0.15 \mathrm{M} \mathrm{NaCl}$-washed purified nuclei with the lysis buffer. About 60 percent of the nuclear proteins in both the trypsinized and scraped cells were solubilized in the lysis buffer and were free from DNA that might disturb the separation by isoelectric focusing (Table 2).

Urea-insoluble proteins mainly were comprised of the proteins found near the dye front in the SDS polyacrylamide gel electrophoretogram (Fig. 3b); these low molecular weight proteins were identified as histones by acid-urea gel electrophoresis analysis (Fig. 3d). The absence of histone $\mathrm{H} 1$ in Fig. $3 \mathrm{~b}$ may be due to the relatively incomplete staining of $\mathrm{H} 1$ or to degradation of $\mathrm{Hl}$ during dialysis. Urea-soluble acidic proteins contained no detectable amount of histones (Fig. 3c). The band that

TABLE 2. AsSESSMENT OF DNA CONTAMINATION

\begin{tabular}{|c|c|c|c|c|}
\hline \multirow{3}{*}{ Fraction } & \multicolumn{4}{|c|}{ TCA insoluble radioactivities } \\
\hline & \multicolumn{2}{|c|}{$\begin{array}{l}\text { L-[ }{ }^{35} \text { S]-Methionine } \\
\text { (cpm) }\end{array}$} & \multicolumn{2}{|c|}{$\begin{array}{c}{\left[{ }^{3} \mathrm{H}\right]-\text { Thymidine }} \\
(\mathrm{cpm})\end{array}$} \\
\hline & $(\mathrm{T})^{\mathrm{a}}$ & $(\mathrm{R})^{\mathrm{a}}$ & $(\mathrm{T})$ & $(\mathrm{R})$ \\
\hline Nuclei & & 906,750 & & \\
\hline Urea-soluble acidic proteins & $1,262,672$ & 543,600 & 10 & 560 \\
\hline Urea-insoluble proteins & 878,100 & 398,100 & 35,702 & 95,580 \\
\hline
\end{tabular}

TIG-1 cells at 27 PDL were labeled with $\mathrm{L}-\left[{ }^{35} \mathrm{~S}\right]-$ methionine or $\left[{ }^{3} \mathrm{H}\right]$-thymidine as described in Materials AND Methods. Cells were harvested either by treatment with trypsin or by scraping them off with a rubber policeman. At each point in the isolation procedure, replicate samples were taken to determine $\left[{ }^{35} \mathrm{~S}\right]$ and $\left[{ }^{3} \mathrm{H}\right]$ radioactivity by liquid scintillation counting. TCA was added (final $20 \%(\mathrm{w} / \mathrm{v})$ ); precipitates were collected on glass fiber filters, then counted in a toluenebased scintillation cocktail.

${ }^{a}(T)$ and $(R)$ represent trypsin and the rubber policeman, respectively. 


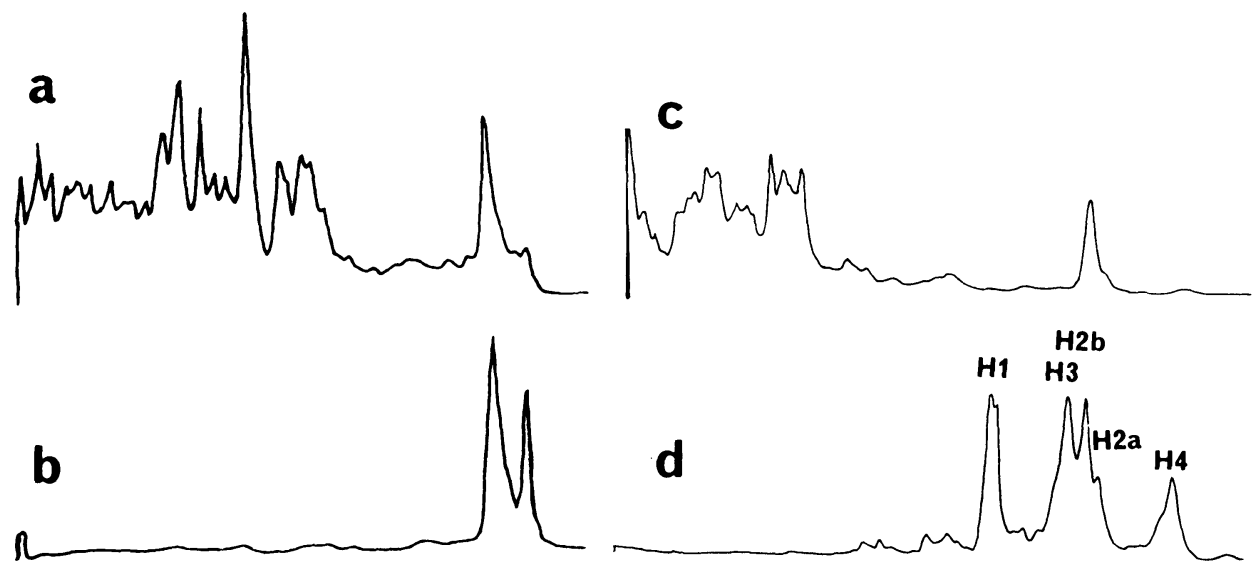

Fig. 3. Identification of histones in the urea-insoluble protein fraction. Each protein fractionated from 27 PDL cells was solubilized and subjected to SDS polyacrylamide gel electrophoresis $(a, b)$ or to acid-urea polyacrylamide gel electrophoresis (c, d) as decribed in MATERIALS AND METHODS. Migration was from left to right. $(a, c)$ Urea-soluble nuclear acidic proteins and $(b, d)$ urea-insoluble nuclear proteins.

appeared at the position of histone $\mathrm{H} 2 \mathrm{~b}$ in Fig. $3 \mathrm{c}$ might be low molecular weight nonhistone proteins that have a positive charge and migrate to the same position as $\mathrm{H} 2 \mathrm{~b}$ in the acid-urea gel system. Therefore, the urea-soluble nuclear acidic proteins mainly are comprised of many proteins common to residual acidic proteins, that do not contain histones and are mostly acidic proteins.

Fig. 4 shows two autoradiographies of $\left[{ }^{35} \mathrm{~S}\right]-$ methionine-labeled, urea-soluble nuclear acidic proteins separated by two-dimensional gel electrophoresis. The nuclear proteins from young (Fig. 4A) and senescent cells (Fig. 4B) separated into superimposable patterns. More than 200 separate spots, representing polypeptide species of unique charge and molecular weight, were detectable in each gel after 10 days of auto-

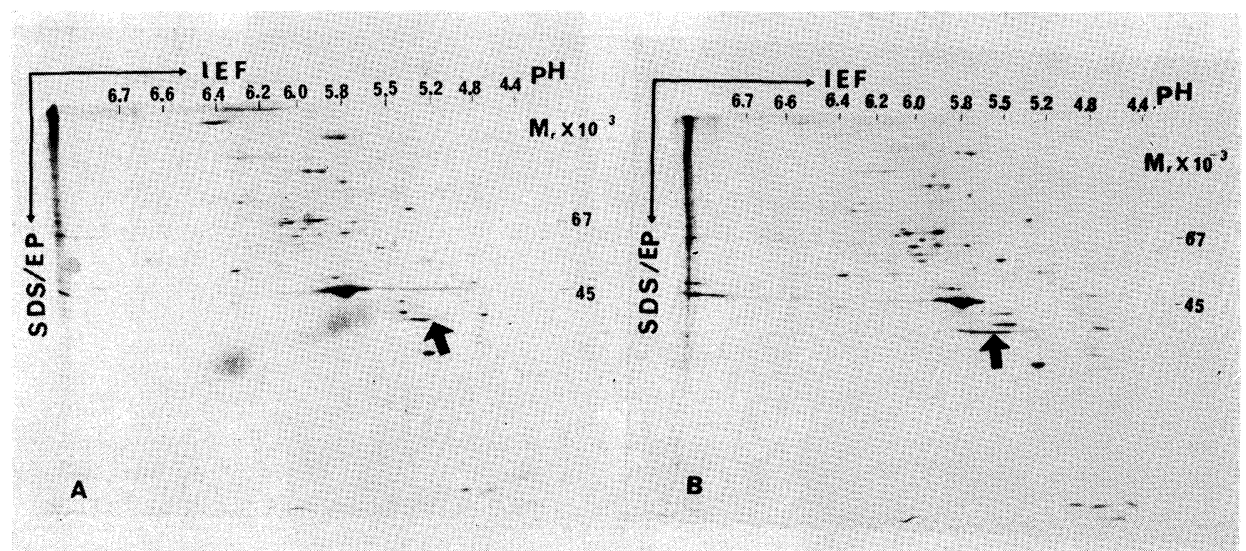

Fig. 4. Autoradiographies of two-dimensional gels of urea-soluble nuclear acidic proteins from (A) young (27 PDL) and (B) senescent (54 PDL) TIG-1 cells harvested by treatment with trypsin. Electrophoresis was carried out as described in Fig. 2. The first-dimensional isoelectric-focusing gels were loaded with 200,000 TCA insoluble cpm. Autoradiograms were obtained after a 10 day exposure. Arrows indicate spots which shifted slightly from the isoelectric point of 5.3 (A) to 5.8 (B). 

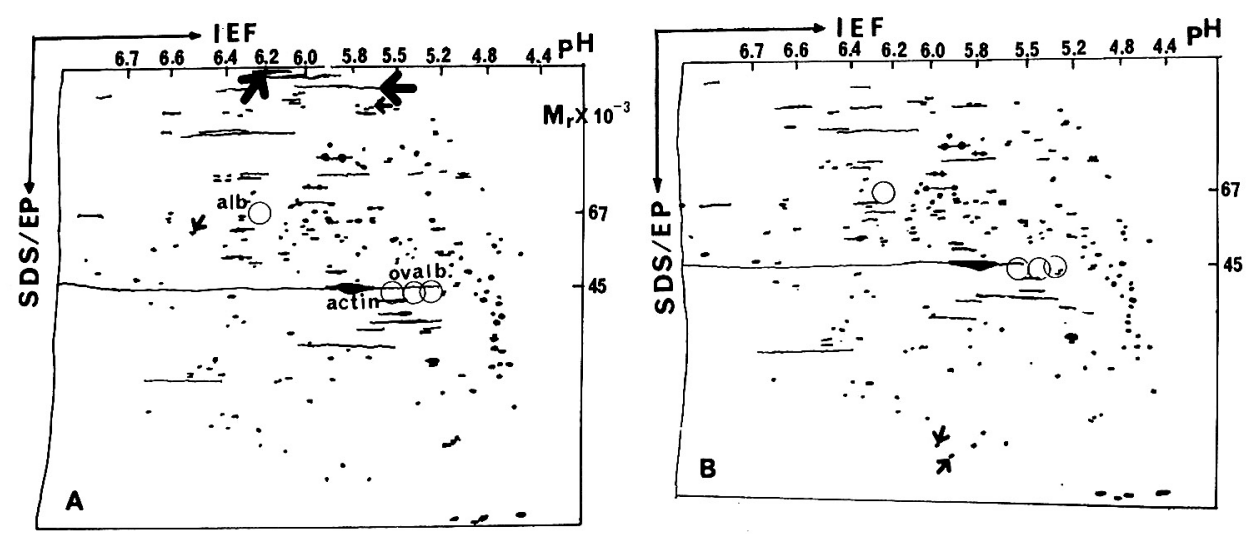

Fig. 5. Schematic diagram of Fig. 4. Urea-soluble nuclear acidic proteins from (A) young (27 PDL); and (B) senescent TIG-1 cells (54 PDL). Arrows indicate proteins present in one cell population but missing or greatly diminished in the other. Albumin (MW 67,000), ovalbumin (MW 45,000 ), and actin (MW 45,000) were included in the labeled samples as marker proteins.

radiographic exposure. Few additional proteins were found when the $\mathrm{pH}$ gradient was increased to $\mathrm{pH} 4.2-7.8$. Actin was the most abundant protein in both cases. Fig. 5 is a diagrammatic comparison of the results in Fig. 4. A comparison of the gel patterns of nuclear acidic proteins from young (Fig. 5A) and senescent cells (Fig. 5B) was carried out by superimposing the autoradiograms of each gel. The arrows point to proteins present in one cell population but missing or greatly diminished in the other cell population. Four spots that are indicated in young cell nuclei (Fig. 5A) are absent or greatly diminished in senescent cell nuclei (Fig. 5B). Two spots that are indicated in senescent cell nuclei (Fig. 5B) are absent in young cell nuclei (Fig. 5A). A spot at molecular weight 37,000 is present only in young cells at the isoelectric point of 5.3

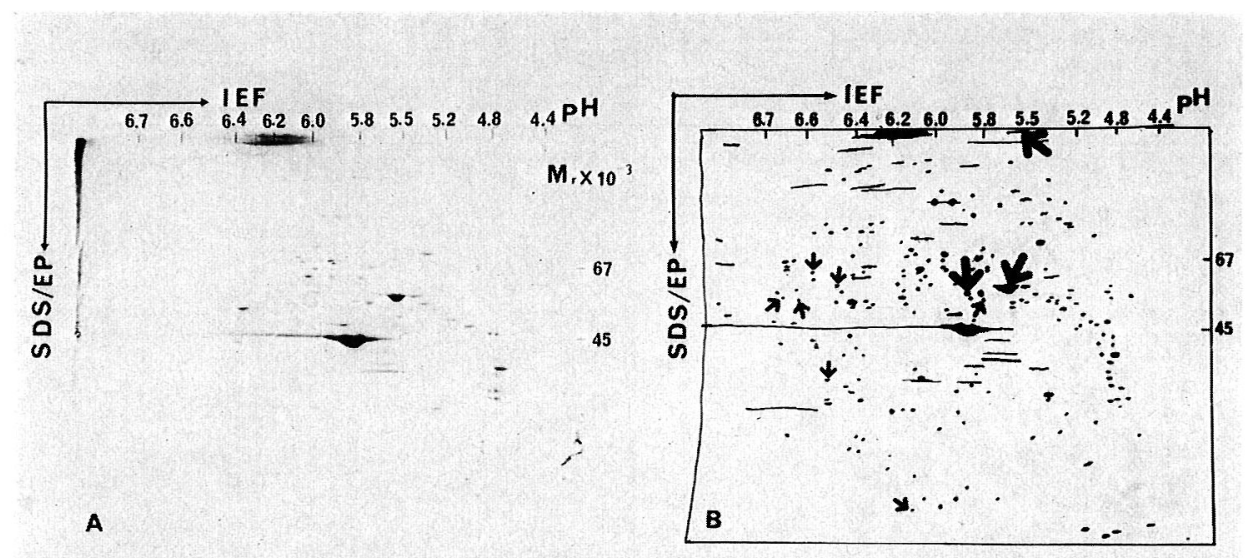

Fig. 6. Autoradiography of a two-dimensional gel of urea-soluble nuclear acidic proteins from young TIG-1 cells (27 PDL) harvested by scraping them off with a rubber policeman. The autoradiogram was obtained after a 10 day exposure. (A) Autoradiogram and (B) schematic diagram of (A). Arrows indicate proteins missing or greatly diminished in the autoradiogram of urea-soluble acidic proteins of trypsinized cell nuclei (Fig. 4A). 
(indicated by the arrow in Fig. 4A); another spot near this one appeared at the same molecular weight but at the different isoelectric point, 5.5-5.8, only in senescent cells (indicated by the arrow in Fig. 4B).

The autoradiography in Fig. 6 shows that scraped cell nuclei contained 3 major and 7 minor acidic proteins (indicated by the arrows in Fig. 6) that were not detected in trypsinized cell nuclei (Fig. 4A), and about another 200 proteins were completely superimposable on each other. We believe that the 10 acidic proteins present only in scraped cell nuclei may be derived from extranuclear contaminants; thus cell trypsinization probably does not cause degradation of nuclear acidic proteins.

\section{DISCUSSION}

Isolation of purified nuclei without the degradation of nuclear proteins and contamination with extranuclear proteins is essential for the analysis of nuclear proteins. However, the crude and purified nuclei from cells harvested by scraping them off with a rubber policeman always were contaminated with fibrous substances as observed under phase contrast microscopy. Therefore, we used purified nuclei from cells harvested by treatment with $0.25 \%$ trypsin. Cell trypsinization, however, may cause a loss of nuclear proteins (11), and histone $\mathrm{H} 1$ in native chromatin has been reported to be the most susceptible of the nucleohistones to proteases (4). Our present data indicated that the amount of $0.4 \mathrm{~N} \mathrm{H}_{2} \mathrm{SO}_{4}$ extractable protein as well as the proportion of histone $\mathrm{H} 1$ to total histones were not affected by trypsin treatment (Table 1); histone $\mathrm{H} 1$ was not degraded during incubation with lysis buffer as demonstrated by the complete recovery of $\mathrm{H} 1$ from the urea-insoluble nuclear protein fraction (Fig. $3 d)$. In addition, the two-dimensional gel electrophoretic patterns of urea-soluble proteins were not affected by the addition of a protease inhibitor, PMSF (data not shown); more than 200 acidic proteins of the trypsinized cell nuclei were superimposable completely on those of the scraped cell nuclei as noted in the legend to Fig. 6 . Thus, the artifactual degradation of nuclear proteins by trypsin treatment seems to be negligible for the examination of marked alterations in nuclear proteins with cellular aging.

The increases in cellular and nuclear proteins observed in TIG-1 cells are correlated closely with age-related increases in cell volume and nuclear size in WI-38 cells, as previously reported $(13,15)$.

Since the increase in residual acidic nuclear proteins with aging accounted for 74 percent of the age-related increase in the total nuclear proteins (Table 1), we investigated whether any qualitative alterations of nuclear acidic proteins were induced with aging. Two-dimensional electrophoretic analysis of this fraction revealed agerelated changes in seven polypeptides out of 200 major polypeptide species. Four proteins were present in young cells, but absent or greatly diminished in senescent cells, and two proteins were found only in senescent cells (Fig. 4, 5). The isoelectric point of a single polypeptide at the molecular weight of 37,000 seemed to shift from 5.3 (at early passage) to 5.8 (at late passage). This shift in isoelectric point was reproducible in a duplicate sample that underwent two-dimensional gel electrophoresis at the same time. This shift may be explained by the dephosphorylation of protein, because phosphorylation produced a horizontal series of spots in the two-dimensional pattern (19). Some of these changes possibly may have resulted from a change in the amino acid composition of the polypeptide (2), or from other postsynthetic modifica- 
tions (acetylation, methylation, or ADP-ribosylation) or from the binding of cofactors (ATP, etc) to nuclear proteins.

Since the nuclear acidic proteins analyzed here are composed of acidic proteins in the chromatin and nuclear membrane, and in the ribonucleoproteins in the nucleoplasm (1), further fractionation of these proteins is necessary to analyze more fully the possible alterations.

Aknowledgments. We wish to thank Mr. K. Matsuoka of this laboratory for providing the TIG-1 cells at different stages of in vitro passage. Thanks are also due to Dr. T. Senshu of this Institute for his invaluable advice on nuclear isolation techniques. We also thank Dr. S. Fujita of the University of Tokyo for his kind demonstration of two-dimensional gel electrophoresis. This work was supported in part by a project grant from the Institute of Physical and Chemical Research, and by a grantin-aid from the Ministry of Education, Science, and Culture, Japan.

\section{REFERENCES}

1. Bhorjee, J. S. and T. Pederson. Chromatin: Its isolation from cultured mammalian cells with particular reference to contamination by nuclear ribonucleoprotein particles. Biochemistry 12, 2766-2773, 1973

2. Buchanan, J. H. and A. Stevens. Fidelity of histone synthesis in cultured human fibroblasts. Mech. Ageing Develop. 7, 321-334, 1978

3. Burton, K. A study of the conditions and mechanism of the diphenylamine reaction for the colorimetric estimation of deoxyribonucleic acid. Biochem. J. 62, 315-323, 1956

4. Chong, M. T., W. T. Garrard and J. Bonner. Purification and properties of a neutral protease from rat liver chromatin. Biochemistry 13, 5128-5134, 1974

5. Dell'Orco, R. T., P. L. Guthrie and D. L. Simpson. Age related alterations in the chromosomal proteins from human diploid fibroblasts. Mech. Ageing. Develop. 8, 435-444, 1978.

6. Hayflick, L. The limited in vitro lifetime of human diploid cell strains. Exp. Cell Res. 37, 614636,1965

7. Hayflick, L. and P. S. Moorhead. The serial cultivation of human diploid cell strains. Exp. Cell Res. 25, 585-621, 1961

8. Kaftory, A., P. Weisman-Shomer and M. Fry. DNA binding proteins in growing and resting young and senescent cultured chick fibroblasts. Mech. Ageing Develop. 8, 75-84, 1978

9. LaEmmli, U.K. Cleavage of structural proteins during the assembly of the head of bacteriophage T4. Nature 227, 680-685, 1970

10. Lowry, O. H., N. J. Rosenbrough, A. L. Farr and R. J. Randall. Protein measurement with Folin phenol reagent. J. Biol. Chem. 19, 265-275, 1951

11. Maizel, A., C. Nicolini and R. Baserga. Effect of cell trypsinization on nuclear proteins of WI-38 fibroblasts in culture. J. Cell. Physiol. 86, 71-82, 1974

12. Maizel, A., C. Nicolini and R. Baserga. Structural alterations of chromatin in phase III WI38 human diploid fibroblasts. Exp. Cell Res. 96, 351-359, 1975

13. Mitsui, Y. and E. L. SCHNEIDER. Relationship between cell replication and volume in senescent human diploid fibroblasts. Mech. Ageing Develop. 5, 45-56, 1976

14. Mitsui, Y. and E. L. Schneider. Increased nuclear sizes in senescent human diploid fibroblast cultures. Exp. Cell Res. 100, 147-152, 1976

15. Mitsui, Y. and E. L. SCHNEIDER. Characterization of fractionated human diploid fibroblast cell populations Exp. Cell Res. 103, 23-30, 1976

16. Nooden, L. D., H. W. J. van den Broek and J. S. Sevall. Stabilization of histones from rat liver. FEBS Lett. 29, 326-328, 1973

17. O'Farrell, P. H. High resolution two-dimensional electrophoresis of proteins. J. Biol. Chem. 250, 4007-4021, 1975

18. Panyim, S. and R. Chalkley. High resolution acrylamide gel electrophoresis of histones. Arch. Biochem. Biophys. 130, 337-346, 1969 
19. Peterson, J. L. and E. H. McConkey. Non-histone chromosomal proteins from HeLa cells. A survey by high resolution, two-dimensional electrophoresis. J. Biol. Chem. 251, 548-554, 1976

20. Ryan, J. M. and V. J. Cristofalo. Histone acetylation during aging of human cell in culture. Biochem. Biophys. Res. Commun. 48, 735-742, 1972

21. Schneider, E. L., K. Braunschweiger and Y. Mitsui. The effect of serum batch on the in vitro lifespans of cell cultures derived from old and young human donors. Exp. Cell Res. 115, 47-52, 1978

22. SChNeIDer, E. L. and Y. Mitsui. The relationship between in vitro cellular aging and in vivo human age. Proc. Natl. Acad. Sci. U.S.A. 73, 3584-3588, 1976

23. Senshu, T. and M. Ohashi. Fractionation of unfixed chromatin by buoyant-density centrifugation in gradients containing 3-Iodo-1,2-propanediol and Metrizamide. J. Biochem. 83, 639646,1978

24. SRivastava, B. I. S. Changes in enzymic activity during cultivation of human cells in vitro. Exp. Cell Res. 80, 305-312, 1973

25. Stein, G. H. DNA-binding proteins in young and senescent normal human fibroblasts. Exp. Cell Res. 90, 237-248, 1975

26. Stein, G. S. and T. W. Borun. The synthesis of acidic chromosomal proteins during the cell cycle of HeLa S-3 cells. I. The accelerated accumulation of acidic residual nuclear protein before the initiation of DNA replication. J. Cell Biol. 52, 292-307, 1972

27. Wright, W. E. and L. HAYFLICK. Nuclear control of cellular aging demonstrated by hybridization of anucleate and whole cultured normal human fibroblasts. Exp. Cell Res. 96, 113-121, 1975

(Received for publication, August 15, 1979) 